\title{
精神作業によって生じた生理変化の回復に関する検討
}

○黒坂 知絵 (産業医科大学産業保健学部), 倉岡 宏幸 (九州工業大学大学院生命体工学研究 科), 鶴原一樹(産業医科大学大学院医学研究科), 三宅 晋司 (産業医科大学産業保健学部)

\section{Recovery of Physiological Changes induced by Mental Task}

Chie KUROSAKA (School of Health Sciences, University of Occupational and Environmental Health, Japan), Hiroyuki KURAOKA (Graduate School of Life Sciences and Systems Engineering, Kyushu Institute of Technology), Kazuki TSURUHARA (Graduate School of Medical Science, University of Occupational and Environmental Health, Japan), Shinji MIYAKE (School of Health Sciences, University of Occupational and Environmental Health, Japan)

\section{1.はじめに}

現代社会において日常生活で受けるストレスは 増加し，様々な検討が行われている．経済産業省 の技術戦略においても, 生活内の機器によってス トレスを計測し，五感への刺激等でストレスを軽 減するシステムの確立が2030年までの目標として 掲げられている1). 精神的ストレスによる生理反 応は, ストレッサーの強さや種類, 心理的要因, 生理学的要因など, 様々な影響を受けることが先 行研究にて報告されている2,3)。生体計測にてス トレスの軽減を評価しようとした場合，ストレッ サーによる生理反応だけではなく, ストレッサー がなくなったときの反応における検討も必要であ る. 本稿では, 精神作業によって生じた生理変化 の回復に関係する要因を探ることを目的とした.

\section{2. 実験方法}

精神作業中とその前後の安静時において, 心電 図および主観評価の計測を行った。精神作業は, 暗算課題（以下，MA）および鏡映描写課題（以下, MT)，主観評価は, Stress Arousal Checklistの うちストレス評価項目17設問（以下，SACL）とメ ンタルワークロード評価としてNASA-TLX（以下， TLX）を用いた。被験者は，20～60歳代の健康な 男女105名（各年齢群10～12名）で，予め書面に よる同意を得た。実験は，作業前安静（以下， PRE), SACL, 精神作業1, TLX, 精神作業2, TLX, SACL，作業後安静記録（以下，POST）の順で行っ た. 全被験者がMAおよびMTを1回ずつ遂行し，生 理量計測は各5分間とした。なお，精神作業の遂 行順序は被験者間で相殺した。

\section{3. 解析方法}

胸部より計測した心電図よりRRIを算出し，被 験者別に, 作業前後の安静時と精神作業時の各ブ
ロックにおいて平均值を計算した，RRIの回復值 として，PREとPOSTの差值（ $\triangle \mathrm{RRI}=\mathrm{POST}-\mathrm{PRE})$ を 算出した. 本稿では2種類の精神作業の違いにつ いては検討しないため, 精神作業 1 と 2 の平均值 （TASK）を精神作業時のRRI とした。回復值に影 響を及ぼす可能性のある因子として，PREおよび POSTに対するTASKの変化率（\%PRE，\%POST）も算 出した.

$\triangle \mathrm{RRI} ％ \mathrm{PRE} ％$ POSTの3つを従属変数として, 主観評価, 作業成績, 被験者の個人特性のすべて の組み合わせについて解析を行った．主観評価は， 作業前後のSACL值（SACL_Bef，SACL_Aft）, TLXの AWWL（MT_AWWL，MA_AWWL)，作業成績は，MTは総 距離を逸脱回数で除算した值（MT_Perf）, MAは平 均正答レベル (MA_Perf), 被験者の個人特性は年 齢と性別とした.

性別に関してはt検定，性別以外の変数におい ては, ピアソンの積率相関係数を求め, 有意検定 を行った．また，相関関係が認められた個人特性 については，年齢を20～60歳台の5群とし，年齢

(AGE) と性別（SEX）を要因として二要因分散分析 を行った（SPSS ver.19）. 多重比較にはTukey HSDの方法を用いた.

\section{4. 結果}

$\triangle R R I$ と主観評価には，いずれも相関は認めら れなかった。作業成績に関しては，MT_Perf： $-0.265(\mathrm{p}=0.007, \mathrm{n}=101)$, MA_Perf: $\mathrm{r}=-0.211$ $(\mathrm{p}=0.003, \mathrm{n}=100)$ であった. $\triangle \mathrm{RRI}$ と年齢の相 関係数は， $\mathrm{r}=0.380(\mathrm{p}=0.0001, \mathrm{n}=101)$ であった （図1）。性毎の平均值 \pm SEは，男性 $(n=52)$ : 6.951土4.701, 女性 $(\mathrm{n}=50): 17.15 \pm 4.130$ であ り， t検定の結果，群間に有意差は認められな かった（p=0.107，95\% CI:-22.66〜2.25）. 


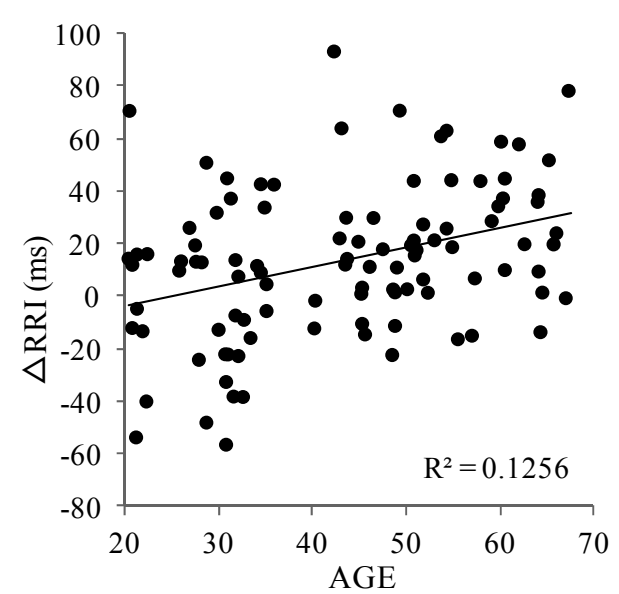

図1: $\triangle R R I$ と年齢の相関図

年齢と性別を要因とした分散分析の結果，\%PRE は性別に，\%OSTは年齢に主効果が認められた (表1). 年齢の多重比較の結果，20歳台と60歳台 （ $\mathrm{p}=0.017 ， 95 \% \mathrm{CI}: 0.709-11.0 ）$ および30歳台 と60歳台（ $\mathrm{p}=0.020 ， 95 \% \mathrm{CI}: 0.620-10.9)$ に有 意差が認められた。 なお，両者ともに交互作用は 認められなかった。

表1：分散分析の結果

\begin{tabular}{llccl}
\hline & & 自由度 & F値 & \multicolumn{1}{c}{$\mathrm{p}$} \\
\hline \multirow{2}{*}{$\%$ PRE } & SEX & 1 & 5.557 & $0.021^{*}$ \\
& AGE & 4 & 1.494 & 0.211 \\
& SEX*AGE & 4 & 0.363 & 0.835 \\
\hline \multirow{2}{*}{$\%$ POST } & SEX & 1 & 0.616 & 0.435 \\
& AGE & 4 & 3.700 & $0.008^{* *}$ \\
& SEX*AGE & 4 & 0.874 & 0.483 \\
\hline
\end{tabular}

$\triangle R R I$ との相関係数は, \%PRE : $r=-0.057$ $(\mathrm{p}=0.567, \mathrm{n}=101), \%$ POST $: \mathrm{r}=0.549 \quad(\mathrm{p}=0.0000$, $\mathrm{n}=101)$ であった．年齢 $\times$ 性別群におけるRRIの変 化率を図2に示す.

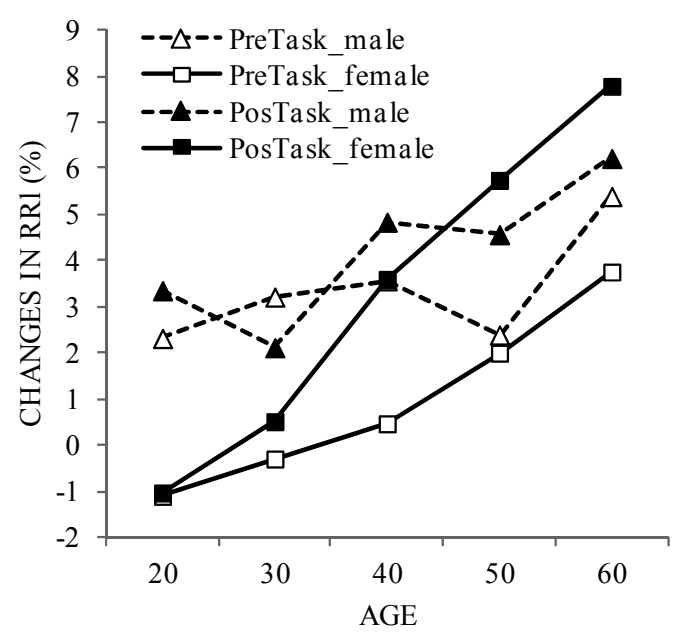

図2 : RRIの変化率と個人特性

\section{5. 考察}

相関係数の結果から， $\Delta R R I$ と作業成績の相関 係数は有意であったものの，その值は小さく，強 い相関があるとは言い難い。すなわち，RRIの回 復值には主観評価や作業成績よりも，被験者の年 齢の影響が大きい可能性が示唆された。また， RRIの回復值には，精神作業開始よりも終了後の 生理変化が影響していることも示された. 多重比 較にて有意差が認められた群は一部であったが, 図2より，年齢が上がるとRRI変化率も増加する傾 向があり，その傾向は男性よりも女性の方が顕著 であった．生体計測を行う実験では，被験者の条 件統一や実験者の性別などの関係で，若年層の男 性を被験者とするケースが多い. 安静一作業間に おけるRRIの変化に関しては，女性被験者は年齢 の影響を受けること，若年層においては男性と女 性で異なる傾向がある可能性を念頭におくことも 必要かもしれない，ただし，今回の実験は男性と 女性とで実験場所が異なったため性差による考察 は今後の課題としたい.

精神作業によって血中のへマトクリット值が上 昇すると生理量の回復に時間が要するという報告 4)もあり，生理量によって回復時間が異なる可能 性がある. 様々な生理量における検討も今後の課 題である.

\section{参考文献}

1）経済産業省：技術戦略マップ 2010, Retrieved April 4, 2016, available from http://www. meti. go. jp/policy/economy/gi j utsu_kakushin/kenkyu_kaihatu/str2010/a7_ 1. pdf

2) Guido, H.E. et al. : Cardiovascular, electrodermal, and performance effects. Psychophysiology, 42, 595-603, 2005.

3) Iani, C. et al. : Effects of task difficulty and invested mental effort on peripheral vasoconstriction, Psychophysiology, 41, 789-798, 2004.

4) Dolf, D. B. et al. : Time course and mechanisms of mental stress-induced changes and their recovery: Hematocrit, colloid osmotic pressure, whole blood viscosity, coagulation times, and hemodynamic activity, Psychophysiology, 44, 639-649, 2007. 